\title{
South-South trade liberalisation and shipping geography: a case study on India, Brazil, and South Africa
}

\section{Tsung-Chen Lee}

Department of Economics, National Taipei University, 151, University Rd., San Shia District, New Taipei City, 23741, Taiwan

E-mail: tclee@mail.ntpu.edu.tw

\section{Paul T.W. Lee*}

Department of Logistics and Shipping Management, Kainan University,

No. 1, Kainan Road, Luzhu Shiang, Taoyuan 33857, Taiwan

E-mail: paultwlee@mail.knu.edu.tw

*Corresponding author

\begin{abstract}
Freer South-South trade has been recognised as a vital engine for the developing countries to reap the maximum economic gains from multilateral trade liberalisation. One of the latest developments which draws considerable attention is the proposed free trade agreement among India, Brazil, and South Africa, namely IBSA, given the fact that the three countries are amongst the leading economies in the continents of South Asia, South America, and Africa, respectively. This paper applies a global computable general equilibrium model, Global Trade Analysis Project, and a converting approach to quantify the impacts of the IBSA trade liberalisation on seaborne cargo volumes. The major advantage of the GTAP model is that it can capture the effects of economy wide adaptation and asymmetric structure change in exports and imports caused by trade liberalisation. Based on our numerical results, removing high tariffs in the South-South trading routes reduces the significance of geographical distance in determining South-South trade patterns, and promotes distant trade with faraway countries.
\end{abstract}

Keywords: South-South trade; trade liberalisation; computable general equilibrium; Global Trade Analysis Project; GTAP; container shipping; India; Brazil; South Africa.

Reference to this paper should be made as follows: Lee, T-C. and Lee, P.T.W. (2012) 'South-South trade liberalisation and shipping geography: a case study on India, Brazil, and South Africa', Int. J. Shipping and Transport Logistics, Vol. 4, No. 4, pp.323-338.

Biographical notes: Tsung-Chen Lee holds a $\mathrm{PhD}$ from Department of Applied Economics and Management, Cornell University, USA. She is currently an Associate Professor at Department of Economics, National Taipei University, Taiwan. She has participated in the projects regarding port development policies in South Africa during 2008-2011. Her recent research interests include, among others, economic and environmental impact analysis 
of port-related activities, as well as the impacts of trade liberalisation on the seaborne cargo volumes.

Paul T.W. Lee is Professor at Department of Logistics and Shipping Management and Director of Shipping Management, Port and Logistics Research Centre at Kainan University in Taiwan. He is also currently holding Research Fellowship of Jungseok Research Institute of International Logistics and Trade at Inha University in Korea. He was a Visiting Scholar at, among others, the Faculty of Economics and Politics in Cambridge, IMS at the University of Plymouth, Hong Kong Polytechnic University, and Dalian Maritime University. He has deeply involved in advising and consulting jobs for several governments, major shipping lines and container ports in the world.

This paper is a revised and expanded version of a paper entitled 'South-South trade liberalisation and shipping geography: a case study of IBSA' presented at The 4th International Conference of Asian Shipping and Logistics, National Cheng Kung University, Tainan, Taiwan, 5-6 May 2011.

\section{Introduction}

International shipping and commodity trade are closely related to each other. On one hand, international shipping accounts for the carriage of about $90 \%$ of world trade, and it is a prime factor of accomplishing economic gains from international commodity trade. On the other hand, international trade drives the business of international shipping. Trade liberalisation, as an economic development strategy in many countries over the past two decades, implies a dramatic change in derived demand for international shipping, as well as in the international shipping geography.

Trade liberalisation between developing countries, generally referred to as freer South-South trade, has attracted considerable attention under the Doha Development Agenda at the World Trade Organisation (WTO), because it offers the developing countries a wide range of economic benefits and growth opportunity. Recent research indicates that South-South trade liberalisation is at least as important as barrier-free market access to the northern (developed) countries (Kowalski and Shepherd, 2006). At present, merchandise trade plays an important dimension in South-South trade, and this trade has much higher barriers, as compared with North-South and North-North trade (OECD, 2006). Given the attribute of high barriers in merchandise trade in South-South routes, the South-South trade liberalisation is expected to cause a substantial change in the movement of cargoes, consequently changing the derived demand for international shipping service.

By and large, the literature on South-South trade places a special focus on the economic benefits and/or impacts resulting from freer trade among the developing countries (e.g., Sanguinetti et al., 2010; Mayda and Steinberg, 2009; Puri, 2007). In fact, maximising the benefits of freer merchandise trade requires an effective shipping strategy at both national and industry levels. However, the current literature does not offer a thorough assessment of the potential impacts on maritime shipping. The issue is relevant to the practical shipping policy design as well as management of maritime logistics (Song and Lee, 2009), and strengthens our motivation to engage in this work. 
This paper aims at filling the gap in the literature by exploring the implications of the latest development of South-South trade - free trade agreement (FTA) among India, Brazil, and South Africa, namely IBSA - on shipping geography. The IBSA trade liberalisation draws considerable attention, given the facts that:

1 India, Brazil, and South Africa are respectively the leading economies in the continents of South Asia, South America, and Africa

2 IBSA cooperation acts as an excellent role model for the South-South cooperation

3 the IBSA countries have become influential players in international trade, and the formation of IBSA is emblematic of new geography of international trade

(Puri, 2007).

The changes in cargo flows caused by trade liberalisation depend on the existing tariff levels and trade patterns, as well as the economy wide adaptation through resource reallocation and industrial restructure. Hence, the quantitative model used in estimating the associated cargo changes should incorporate the intricate channels linking macro economy, international trade and sea transport sector, and has an explicit treatment of commodity trade barriers in different routes (origin/destination). Accordingly, this paper deploys a global computable general equilibrium (CGE) model with the above features, namely, Global Trade Analysis Project (GTAP) developed by Hertel (1997), to simulate the scenario of IBSA trade liberalisation. The GTAP forecasts of trade value flows are then converted into volume flows via a scientific approach based on the commodity trade statistics database called COMTRADE developed by the United Nations Statistics Division.

The contribution of this paper is threefold. First, although the CGE or GTAP models are widely adopted to analyse the economic impacts of trade liberalisation (e.g., Kitwiwattanachai et al., 2010; Acar et al., 2009; Francois and Wignaraja, 2008; Hertel et al., 2004; Brown et al., 2003), the application in maritime shipping studies concerning trade liberalisation is sparse. Two exceptions are Lee and Lee (2009) and Lee et al. (2011), of which the former attempts to analyse the case of South Africa, and the latter pays due attention to the quantitative impacts of the FTA between Taiwan and China (i.e., the Economic Cooperation Framework Agreement, ECFA) on seaborne cargo volumes. The two works demonstrate how to integrate the GTAP model and database with national customs statistics to quantify the containerisable cargo volumes. In this paper, a practical contribution is made by integrating the GTAP model with the worldwide known, publicly available United Nations COMTRADE database. Second, most of the studies on maritime traffic forecast adopt time series technique and historical data (e.g., Goulielmos and Kaselimi, 2011; Veenstra and Haralambides, 2001), and neglect the irregular change in cargo flows caused by trade liberalisation. This paper bridges the gap in the literature by considering the effects of tariff removal on cargo flows. Finally, it is widely accepted that geography and cargo availability determine the long-term shipping itineraries at a global scale among regions (e.g., Laulajainen, 2010). This paper further highlights the significance of high tariff rates in determining the South-South trade geography. The simulation results shed light on the new trade geography in the south hemisphere after the IBSA trade liberalisation. 


\section{Methodology: GTAP and database}

This paper provides a quantitative analysis of the impacts of a FTA among India, Brazil, and South Africa on the cargo value and volume flows. The analysis is based on the GTAP model and its Version 7 database with the base year of 2004. The GTAP model is a comparative-static, multi-region, multi-sector CGE model. The model captures individual countries' economic activities (e.g., production and consumption), domestic commodity market and factor allocation, as well as countries' interactions in international trade. The GTAP model is appropriate for analysing the ensuing impacts of bilateral or multilateral trade liberalisation, and it is widely adopted in the evaluation of freer trade negotiation.

From the methodological viewpoint, there are two major benefits of using the GTAP model to estimate the change in trade volume. First, the GTAP model builds upon the neoclassical theory of general equilibrium. It is a theoretical sound model that can be used to simulate the economy wide adaptation to trade liberalisation. Second, the GTAP model incorporates the global database of country-to-country trade and tariff protection. Hence, it can capture the asymmetric structural changes in commodity trade arising from tariff reduction.

In the GTAP Version 7 database, there are 113 regions, and each regional economy has five primary factors and 57 production sectors. The five primary factors are land, capital, nature resources, unskilled labour and skilled labour. The 57 production sectors are composed of the agricultural and food processing sectors (sectors 1-25), the manufacturing sectors (sectors 26-42) and the service sectors (sectors 43-57).

Table 1 Regional aggregation for IBSA trade liberalisation analysis

\begin{tabular}{ll}
\hline $\begin{array}{l}\text { Regional } \\
\text { description }\end{array}$ & Comprising the GTAP Version 7 countries/regions \\
\hline India & India \\
Brazil & Brazil \\
South Africa & South Africa \\
China & China \\
Rest of Asia & Hong Kong, Japan, Korea, Taiwan, Rest of East Asia, Cambodia, Indonesia, \\
& Lao People's Democratic Republic, Myanmar, Malaysia, Philippines, \\
& Singapore, Thailand, Viet Nam, Rest of Southeast Asia, Bangladesh, Pakistan, \\
& Sri Lanka, Rest of South Asia \\
Oceania & Australia, New Zealand \\
Rest of South & Argentina, Bolivia, Chile, Colombia, Ecuador, Paraguay, Peru, Uruguay, \\
America & Venezuela, Rest of South America \\
Rest of the & Rest of Oceania, Canada, USA, Mexico, Rest of North America, Costa Rica, \\
world & Guatemala, Nicaragua, Panama, Rest of Central America, Caribbean, Austria, \\
& Belgium, Cyprus, Czech Republic, Denmark, Estonia, Finland, France, \\
& Germany, Greece, Hungary, Ireland, Italy, Latvia, Lithuania, Luxembourg, \\
& Malta, Netherlands, Poland, Portugal, Slovakia, Slovenia, Spain, Sweden, UK, \\
& Switzerland, Norway, Rest of EFTA, Albania, Bulgaria, Belarus, Croatia, \\
& Romania, Russian Federation, Ukraine, Rest of Eastern Europe, Rest of Europe, \\
& Kazakhstan, Kyrgyztan, Rest of Former Soviet Union, Armenia, Azerbaijan, \\
& Georgia, Iran Islamic Republic of, Turkey, Rest of Western Asia, Egypt, \\
& Morocco, Tunisia, Rest of North Africa, Nigeria, Senegal, Rest of Western \\
& Africa, Central Africa, South Central Africa, Ethiopia, Madagascar, Malawi, \\
& Mauritius, Mozambique, Tanzania, Uganda, Zambia, Zimbabwe, Rest of \\
& Eastern Africa, Botswana, Rest of South African Customs Union \\
\hline
\end{tabular}


Table 2 Sectoral aggregation and existing tariff rates for IBSA trade liberalisation analysis

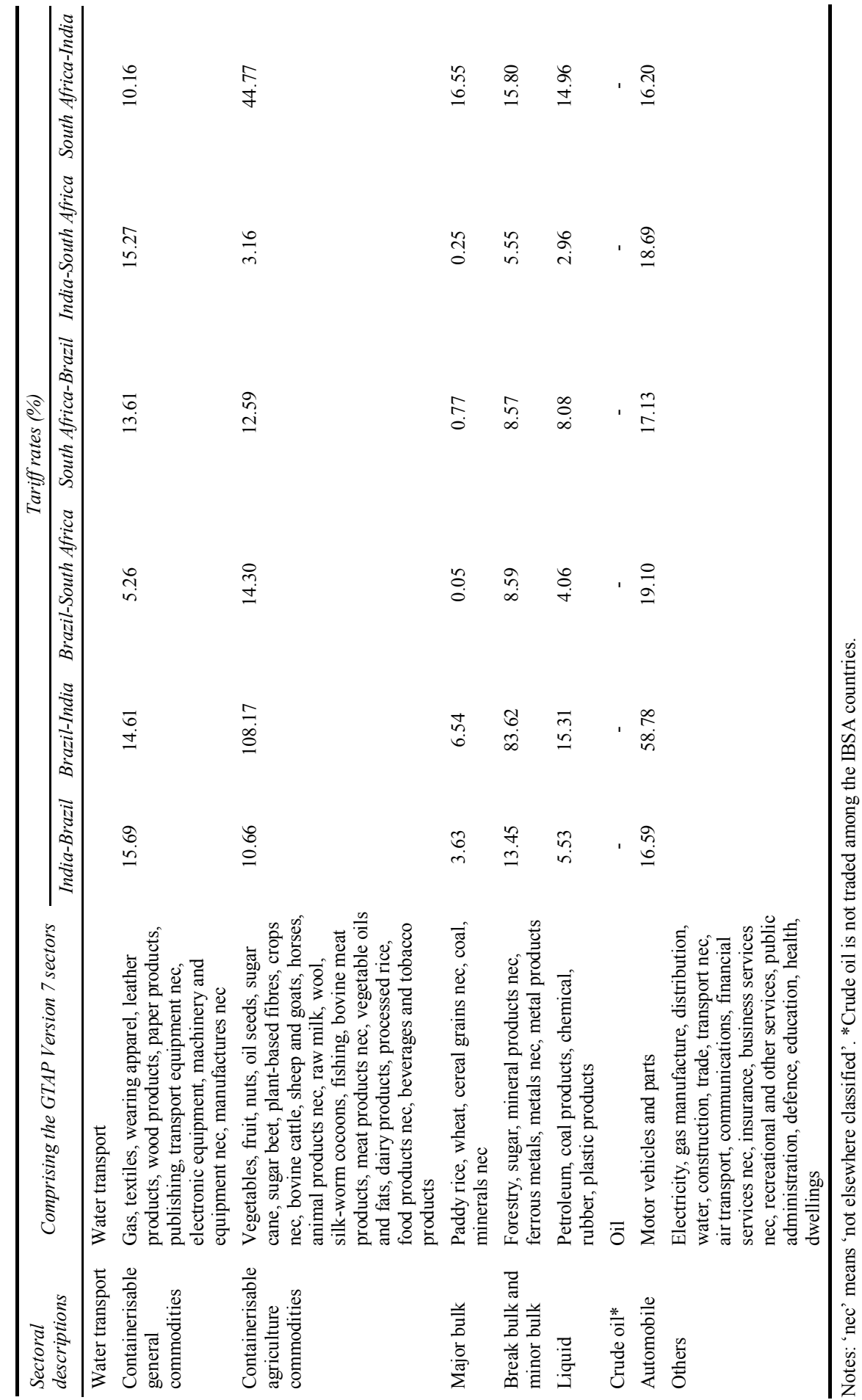


Because the focus of this paper is on the trade between the IBSA countries and their major trading partners, the 113 regions are aggregated into eight countries/regions, consisting of India, Brazil, South Africa, China, Rest of Asia, Oceania, Rest of South America, and Rest of the World. The 57 commodities are aggregated, in light of ship type and relevance to seaborne cargo volume, into nine sectors, comprising water (sea) transport, containerisable general commodities, containerisable agriculture commodities, major bulk, break bulk and minor bulk, liquid, crude oil, automobile, and others. The detailed descriptions of the regional and sectoral aggregations are provided in Tables 1 and 2, respectively.

\section{Analysing the changes in cargo volumes caused by the IBSA trade liberalisation}

This section develops a two-stage procedure to estimate the changes in cargo volume flows caused by the IBSA trade liberalisation. The first step is to simulate the economy wide impacts of tariff removal among the IBSA countries using the GTAP model. Then the conversion factors calibrated according to the United Nations COMTRADE database are used to convert the value flows into volume flows. The detailed forecast procedures and results are described in turn as follows.

In the first step of estimation, we use the GTAP model to simulate the scenario of removing tariffs on commodity trade among India, Brazil, and South Africa. The existing tariff rates of the commodity trade in the six IBSA trade routes are reported in Table 2. Among the three countries, India has the highest tariff protection against the imports from other countries. In particular, India levies relatively high tariff rates on the imports from Brazil, i.e., containerisable agriculture commodities $108.17 \%$; break bulk and minor bulk $83.62 \%$; automobile $58.78 \%$.

Using the GTAP model, we conduct the IBSA trade liberalisation scenario by shocking the exogenous variables of tariff rates in the six IBSA trade routes such that they all reduce to zero. Table 3 reports the value flows in the pre-liberalisation equilibrium and the simulated flow changes caused by the liberalisation. In terms of trade value prior to liberalisation, the dominant trade routes (origin-destination) among the IBSA countries are 'Route 6: South Africa-India' (US \$2,184 millions) and 'Route 3: Brazil-South Africa' (US \$1,099 millions). Regarding individual commodities, the top two traded in the IBSA countries are 'break bulk and minor bulk' (US $\$ 2,330$ millions) and 'liquid' (US \$1,112 millions).

With respect to the trade between individual IBSA countries and the other economies, India has a close trade relationship with 'Rest of Asia' (Route 8: India-Rest of Asia US $\$ 17,251$ millions; Route 12: Rest of Asia-India US $\$ 17,846$ millions). The major commodities traded between India and Rest of Asia include, among others, containerisable general commodities and liquid. Brazil has a close trade relationship with 'Rest of South America' (Route 18: Brazil-South America US \$15,095 millions; Route 22: Rest of South America-Brazil US $\$ 8,555$ millions). Again, containerisable general commodities and liquid are the main commodities traded between Brazil and Rest of South America. South Africa has a close trade relationship with 'Rest of Asia' (Route 24: South Africa-Rest of Asia US \$8,326 millions; Route 28: Rest of Asia-South Africa US $\$ 6,973$ millions). Break bulk and minor bulk and containerisable general commodities are the main commodities traded between South Africa and Rest of Asia. 
Table 3 Value flows of merchandise trade before IBSA trade liberalisation and changes caused by IBSA trade liberalisation

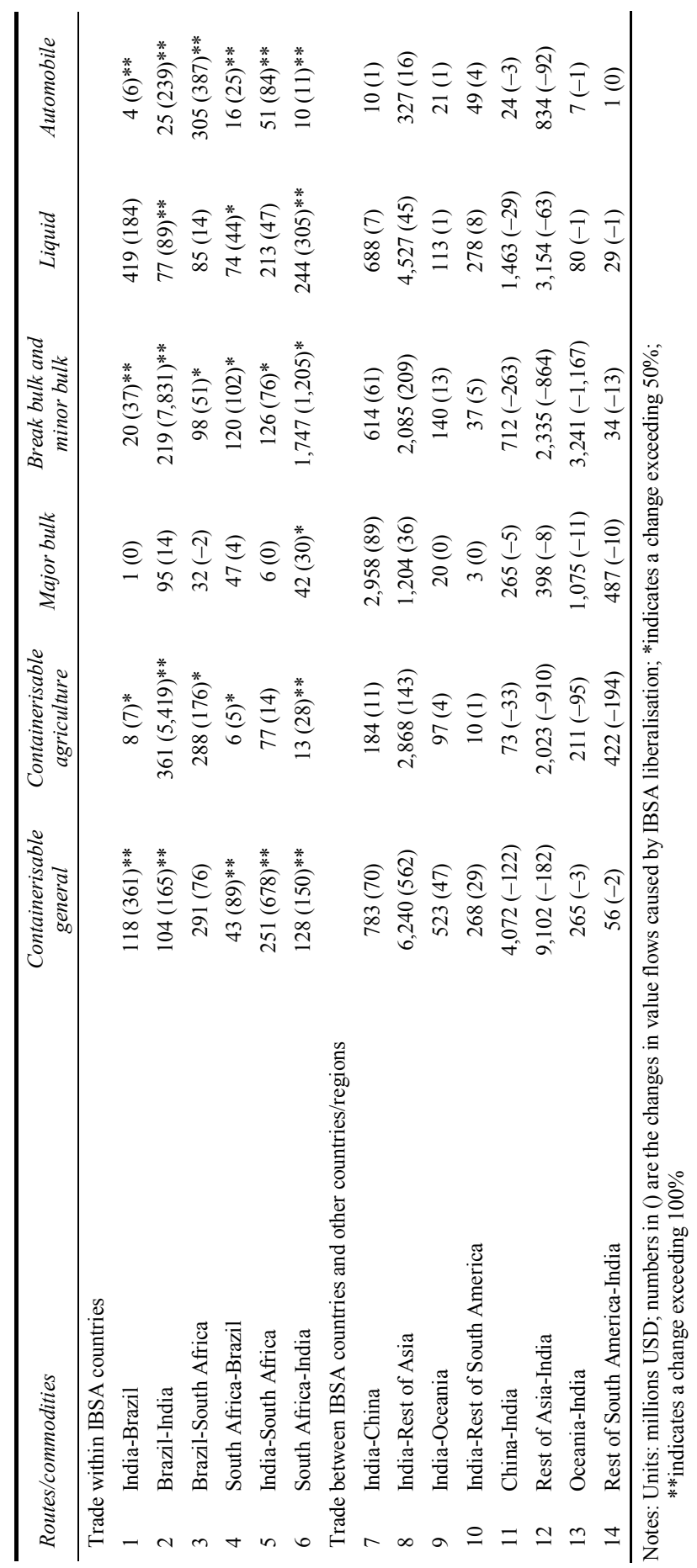


Table 3 Value flows of merchandise trade before IBSA trade liberalisation and changes caused by IBSA trade liberalisation (continued)

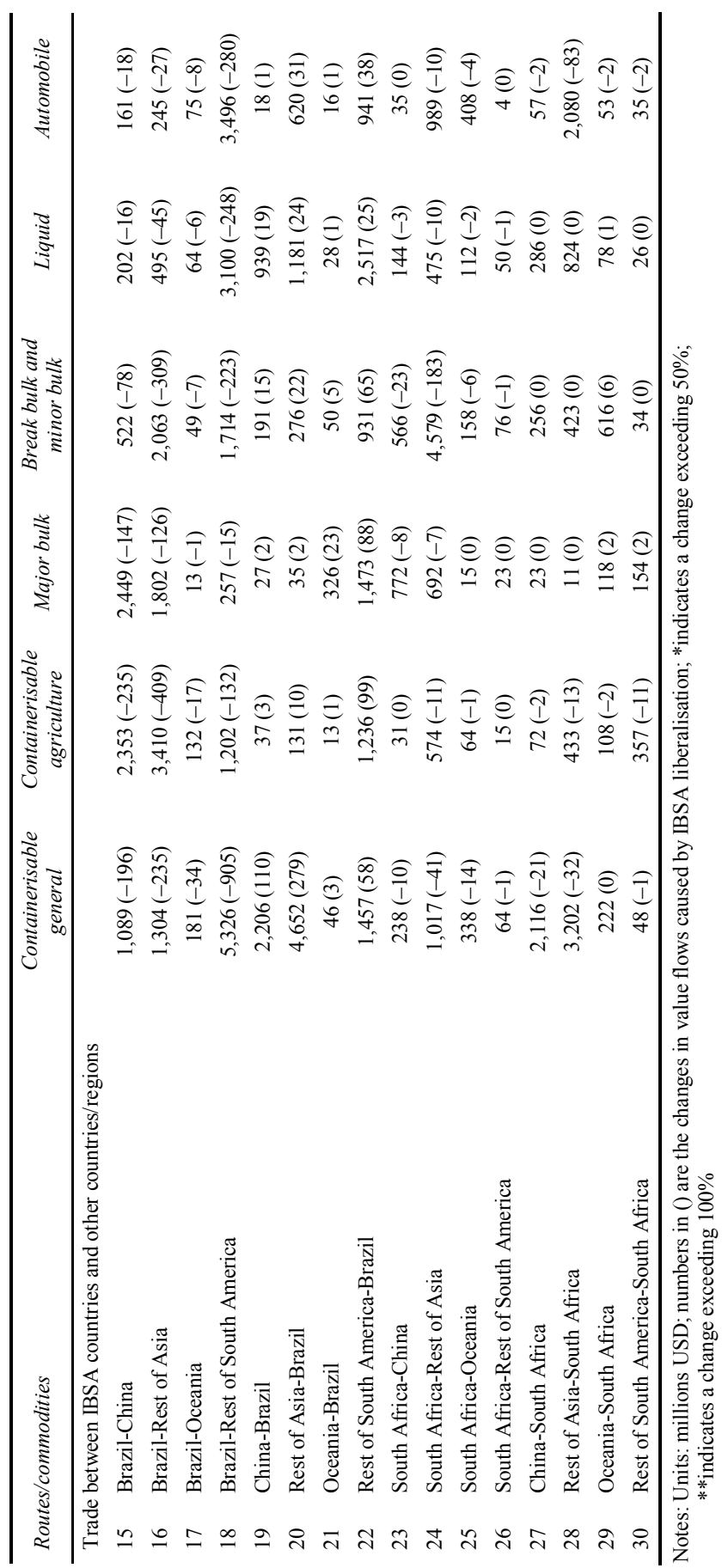


Before the IBSA trade liberalisation, the trade value flows in the six IBSA trade routes are much lower than those in the trade routes between individual IBSA countries and the other economies. The leading trading partners of the IBSA countries are their respective nearby economies, i.e., the major trading partners of India, Brazil, and South Africa are Rest of Asia, Rest of South America, and Rest of Asia, respectively. This fact means that distance is a major factor determining the present trade flows.

The IBSA trade liberalisation will promote the trade within the three countries, and the increase in total trade value is US $\$ 17,951$ millions. Because the existing tariffs on 'Route 2: Brazil-India' are the highest among the IBSA trade routes, tariff removal will lead to a significant increase in the commodity exports from Brazil to India (US \$13,757 millions), and the increase mostly comes from the trade of break bulk and minor bulk (US $\$ 7,831$ millions) and containerisable agriculture commodities (US \$5,419 millions).

As the IBSA countries increase the intra-regional trade, they will reduce trade with the other economies. In particular, India will reduce the imports from the Rest of Asia (US \$2,119 millions). The exports from Brazil to the Rest of South America decrease (US \$1,803 millions). There is also a decrease in the exports from South Africa to Rest of Asia, but the decrease is relatively small (US \$262 millions).

Table 4 Calibrated conversion factors for containerisable cargoes

\begin{tabular}{|c|c|c|c|}
\hline Regional description & $\begin{array}{c}\text { Containerisable } \\
\text { general }\end{array}$ & $\begin{array}{c}\text { Containerisable } \\
\text { agriculture }\end{array}$ & $\begin{array}{l}\text { Break bulk and } \\
\text { minor bulk }\end{array}$ \\
\hline \multicolumn{4}{|l|}{ India } \\
\hline Exports & 272 & 1,876 & 1,927 \\
\hline Imports & 338 & 1,800 & 523 \\
\hline \multicolumn{4}{|l|}{ Brazil } \\
\hline Exports & 630 & 2,045 & 2,697 \\
\hline Imports & 162 & 1,512 & 596 \\
\hline \multicolumn{4}{|l|}{ South Africa } \\
\hline Exports & 955 & 1,003 & 872 \\
\hline Imports & 100 & 1,546 & 1,501 \\
\hline \multicolumn{4}{|l|}{ China } \\
\hline Exports & 108 & 984 & 1,287 \\
\hline Imports & 151 & 1,729 & 1,195 \\
\hline \multicolumn{4}{|l|}{ Rest of Asia } \\
\hline Exports & 145 & 4,897 & 1,764 \\
\hline Imports & 166 & 1,075 & 1,283 \\
\hline \multicolumn{4}{|l|}{ Oceania } \\
\hline Exports & 84 & 1,827 & 221 \\
\hline Imports & 112 & 578 & 885 \\
\hline \multicolumn{4}{|l|}{ Rest of South America } \\
\hline Exports & 884 & 1,909 & 1,144 \\
\hline Imports & 250 & 1,535 & 1,283 \\
\hline
\end{tabular}

Note: Units: tons/ millions USD 
In summary, although Brazil and India are two countries far apart from each others, the trade value in the route of 'Brazil-India' increases significantly if the high trade barrier between them are removed. This result suggests that, in determining new trade geography in the post-liberalisation equilibrium, the long distance factor can be dominated by the trade creation effect of removing high tariffs in South-South trade.

The above results of trade value flows can provide some reference to the directions of cargo movement and growth caused by the IBSA trade liberalisation. However, because the value-to-weight and to-volume ratios are very different across commodities, the results of value flows are not sufficient for a better understanding of derived shipping demand. Given the fact that most cargo is now containerised, this paper calibrates a set of scientific conversion factors based on the United Nations COMTRADE database (see Table 4) to convert the estimated value flows into volume flows of container TEUs (20-foot equivalent units).

To quantify the volume flows, we first calculate the trade weight flows, in units of tons, of a commodity in a particular route through multiplying the average conversion factors of the exporting country (origin) and importing country (destination) by the associated trade value flow. Then the weight flows are converted into TEUs based on the assumptions of ' 12 tons/TEU' for containerisable general commodities and break bulk and minor bulk (European Commission, 2001; Janic, 2007) and '9 tons/TEU' for containerisable agriculture commodities. The volume flow results, in units of TEUs, are reported in Table 5. Given that the trade data in the GTAP database are on a 'direct' trade basis (Gehlhar et al., 2010), our results of volume flows can be seen as the (variations in) direct shipping full containers. The volumes associated with transshipment and empty containers are excluded.

The converted results can be validated by comparing them with the historical statistics prior to the IBSA trade liberalisation. In the pre-IBSA equilibrium, the converted TEUs for India, Brazil and South Africa are 2.85 million TEUs, 3.10 million TEUs, and 1.32 million TEUs, respectively. The historical statistics of container port traffic for India, Brazil and South Africa are 4.33 million TEUs, 5.06 million TEUs and 2.61 million TEUs, respectively. The main reason for such a difference is that our converted results only account for the full containers on a direct shipping basis, but the historical statistics are the container port traffic that also includes the empty containers and transshipment containers. The two groups of numbers will be closer if the empty and transshipment containers are included.

Based on Table 5, the IBSA trade liberalisation will increase the loaded container shipping in the six IBSA trade routes by 2.39 million TEUs, among which $92 \%$ of the volumes ( 2.21 million TEUs) are from Brazil to India. In terms of commodity types, the increase in containers mostly comes from containerisable agriculture commodities (1.20 million TEUs) and break bulk and minor bulk (1.15 million TEUs). The results reflect the fact that India sets high tariff protection against the imports of containerisable agriculture commodities and break bulk and minor bulk, particularly from Brazil. Removing the high tariffs thus causes a significant increase in the cargo volumes. 
Table 5 Volume flows of merchandise trade before IBSA trade liberalisation and changes caused by IBSA trade liberalisation

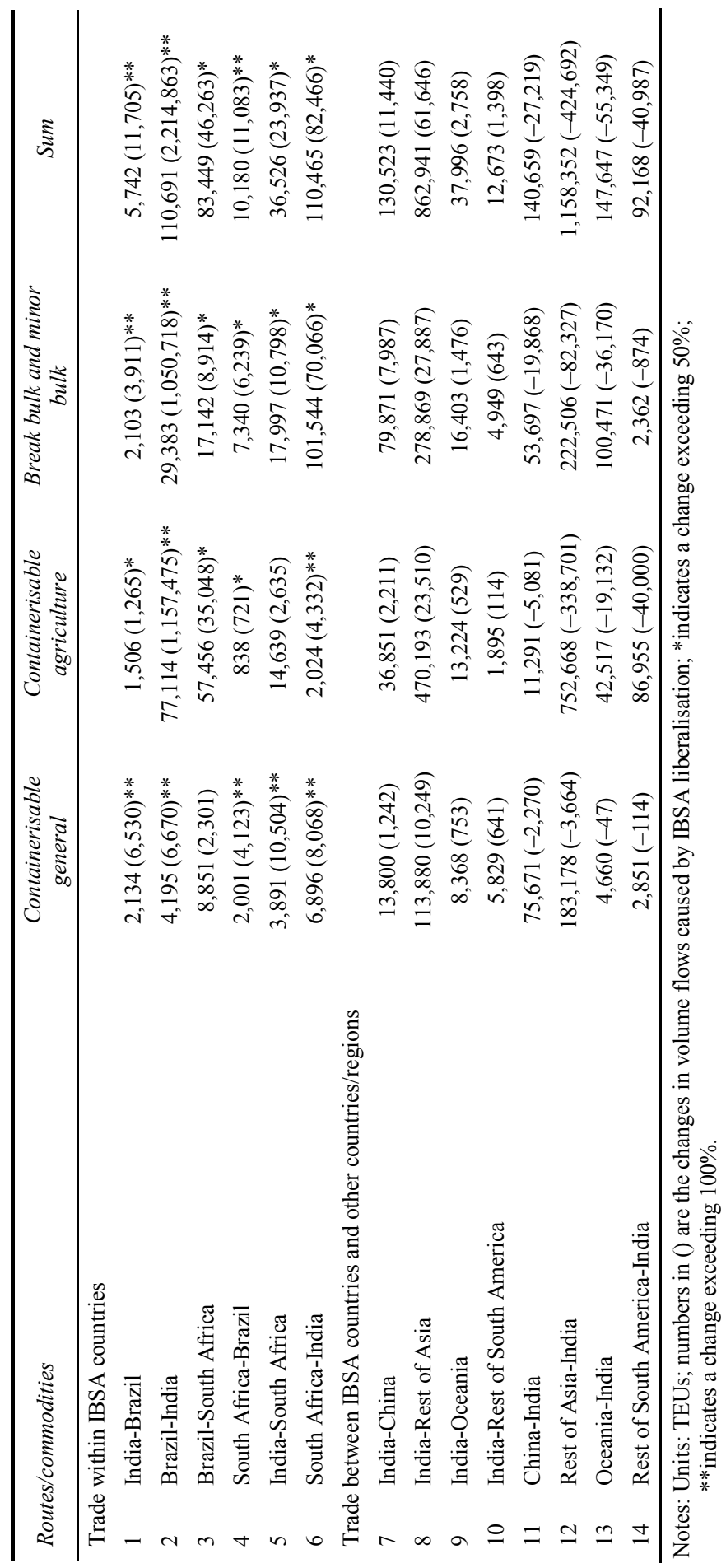


Table 5 Volume flows of merchandise trade before IBSA trade liberalisation and changes caused by IBSA trade liberalisation (continued)

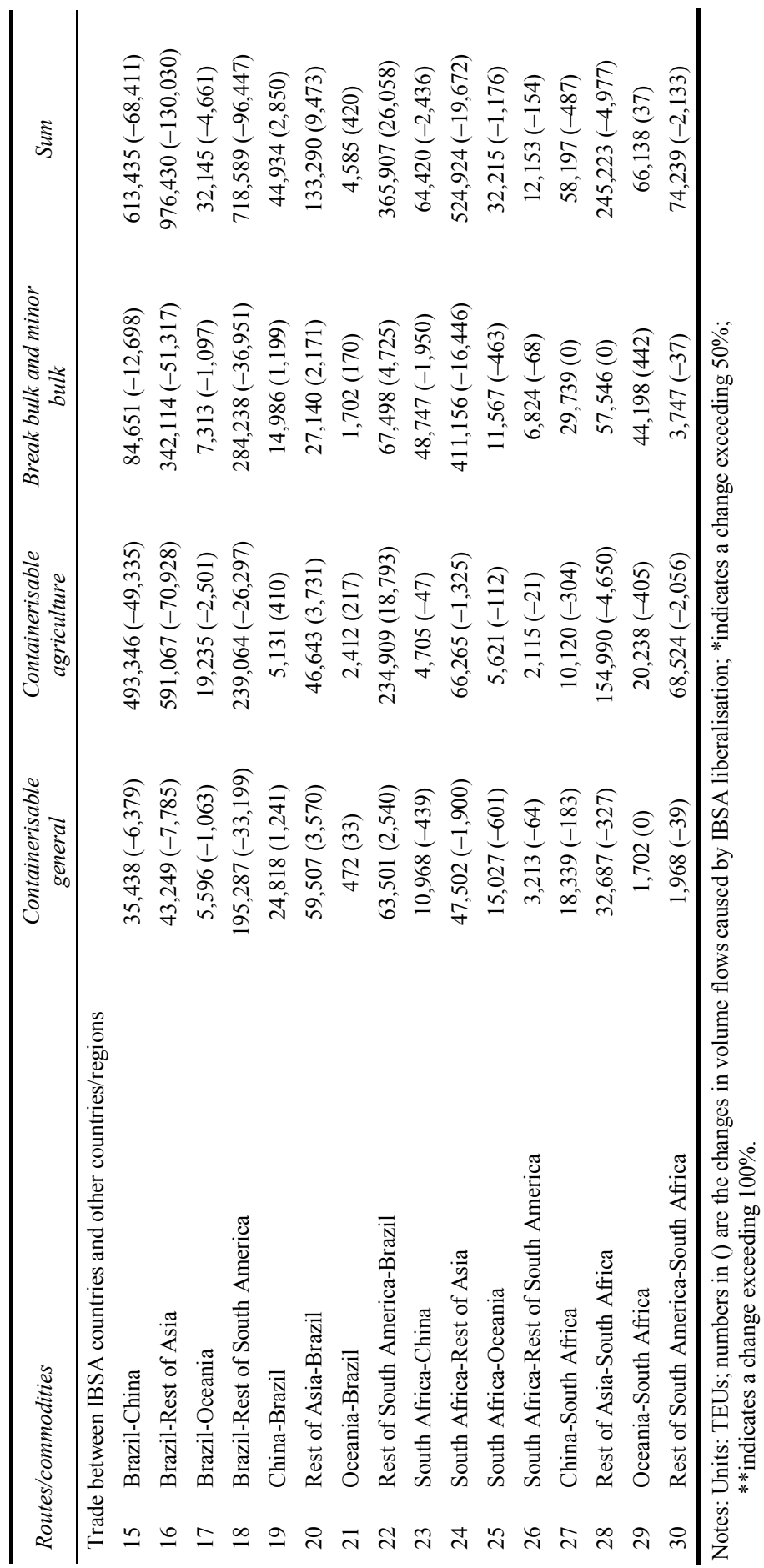




\section{Policy implications and discussions}

The above simulation results suggest that the IBSA liberalisation promotes the intraregional trade, and consequently increases the derived demand for shipping service in the six IBSA trade routes. As noted before, our estimates of the shipping volumes are on a direct trade basis, hence they can be interpreted as the maximum likely increase in demand for the direct shipping in these trade routes. Policy implications are drawn as follows.

First, the IBSA trade liberalisation will lay down a platform to promote merchandise exchange in the three countries, even though the IBSA countries are far away from one another. This liberalisation will also lead to a trade diversion effect of reducing extra-regional trade, particular with their respective nearby countries. As a consequence, there will be more demand for deep sea shipping service within the three countries, as compared with the short sea shipping service from/to other nearby economies. In addition, this result implies an extension of the geographical coverage of major shipping lines' networks towards southern economies. Accordingly, opportunities are envisaged to drive shipping lines to further increase the vessel size or frequencies at a given ship size deployed for the route of India, Brazil, and South Africa. Considering container cargoes generated in China bounding for Africa and South America, transshipment and relay shipping services would be created on the above sea trading routes in association with the feeder networks in the Sub-Saharan Africa. These developments draw special attention to shipping operators and logistics service providers to integrate their service networking on the routes of Shanghai-Hong Kong-Singapore-India-South Africa-Brazil.

Second, this paper provides an ex-ante analysis on the trade flows under the scenario of IBSA trade liberalisation. At present, IBSA countries have developed dialogue forum which provides a platform to engage in discussion for future cooperation, and the IBSA FTA is under negotiation. Even though one may not know when the IBSA FTA will come into effective, the negotiation signifies a dawn. The results of this paper are informative for shipping operators to learn the ensuing impacts on shipping demand caused by the IBSA FTA. Particularly, special attention should be paid to the route of Brazil to India given its significant increase in merchandise trade. In addition, burgeoning engagement of China in trades has been confirmed by the exponential power of 'Chindia' (Engardio, 2006) and 'ChinAfrica' (Beuret and Michel, 2008). This would cause a structural change in commodity trade, derived demand for shipping services, and international logistics structure and services. Asia's increasing involvement in Africa and China's engagement in trade liberalisation on South (North)-South trade have encouraged South Africa to develop a container-port hub as a transport node as well as to capture transshipment cargoes and/or interlining cargoes on this route. In this regard, Ngqura port has been an emerging container hub port in the Sub-Saharan Africa to capture interlining and transshipment cargoes (Lee et al., 2008). South Africa has also been providing a free trade zone and other trade facilities nearby the port (e.g., Ngqura) to develop logistics centres serving Sub-Saharan region. This hub port development is shown not only to be beneficial to the South African economy (Lee et al., 2012), but also to change the South African container port system from a multiple gateway system to a hub port configuration (Notteboom, 2010, 2011). The IBSA liberalisation is expected to contribute to charting a new paradigm of a container hub and spoke development in the African region.

Finally, before the IBSA trade liberalisation, the IBSA countries have a close trade relationship with their nearby countries. This result is consistent with Coulibaly and 
Fontagne (2005) who show that long transit distance is an impediment to international trade. However, the benefits of removing high tariffs among these countries can outweigh the importance of geographical distance, consequently promoting distant trade and increasing the demand for deep sea shipping.

\section{Conclusions}

South-South trade is a vital engine for the developing countries to boost economic development. Given the facts that barriers in intra South trade are relatively high and that merchandise trade plays a key role, reducing South-South tariff barriers can have a major impact on trade flows, consequently changing the derived demand for shipping service. Among the South-South trade liberalisation, the IBSA provides an interesting case study because of the three countries' leading roles in the continents of South Asia, South America, and Africa, respectively. This paper attempts to evaluate the impacts of the IBSA trade liberalisation on the international cargo flows and explores the implications on shipping demand. The major contribution of this paper is to develop a quantitative approach that integrates the GTAP model and the United Nations COMTRADE database to estimate the shipping demand variations in terms of TEUs caused by the IBSA trade liberalisation.

Based on our results, the IBSA trade liberalisation will increase the loaded container shipping in the six IBSA trade routes by 2.39 million TEUs. The route of Brazil to India accounts for $92 \%$ of the increase in volumes (2.21 million TEUs), and the increase mostly comes from containerisable agriculture commodities (1.20 million TEUs) and break bulk and minor bulk (1.15 million TEUs). Given that tariff rates on different commodities among the IBSA countries are of great variety, tariff removal will cause asymmetric impacts on the trade patterns. The impacts on the high tariff products are more significant. Our results also suggest that high tariffs in South-South trade can lead to a distortion in the current trade geography. Therefore, removing these high tariffs will promote distant trade, thus increasing the demand for deep sea shipping.

This paper uses a multi-regional CGE model, GTAP, to estimate the changes in seaborne cargo volumes caused by trade liberalisation. The major advantage of using the GTAP model as a predicting tool is that it can capture the ensuing effects of economy wide adaptation and asymmetric structure change in exports and imports. Because these effects are usually neglected in the studies of maritime transport, the paper contributes to the literature by proposing an alternative forecasting method. However, the GTAP model provides the numerical results at country-to-country levels, thus giving limited insights into the implications on individual ports. This limitation can be remedied if an optimisation model with origin port-destination port analysis is further developed.

Recently, the emergence of China as a major trading partner for several developing countries (e.g., Brazil, Russia, India, China, and South Africa, shortly BRICS) is expected to promote trade volumes and create viable transportation links on these trading routes. BRICS provides another interesting case study because these countries play leading roles in the Group of Twenty (G-20) and are responsible for development agenda in WTO negotiation. The future research can apply the approach proposed in this paper to the case of BRICS, and analyse the associated impacts on shipping network and international maritime logistics service. 


\section{Acknowledgements}

This work was supported by the Research Grant of Jungseok Research Institute of International Logistics and Trade at Inha University (JRI-2011-01).

\section{References}

Acar, M., Alpay, S., Bakimli, E. and Koc, Z.Z. (2009) 'South-East Asian integration in the context of OIC: implications of free trade among Malaysia, Indonesia and Bangladesh', Journal of Economic Integration, Vol. 24, No. 1, pp.1-18.

Beuret, M. and Michel, S. (2008) La Chinafrique, Grasset \& Fasquelle, Paris.

Brown, D.K., Deardorff, A.V. and Stern, R.M. (2003) 'Multilateral, regional and bilateral trade: policy options for the United States and Japan', World Economy, Vol. 26, No. 6, pp.803-828.

Coulibaly, S. and Fontagne, L. (2005) 'South-South trade: geography matters', Journal of African Economies, Vol. 15, No. 2, pp.313-341.

Engardio, P. (Ed.) (2006) Chindia: How China and India are Revolutionizing Global Business, McGraw-Hill, London.

European Commission (2001) 'Real cost reduction of door-to-door intermodal transport, RECORDIT', European Commissions, Directorate General DG VII, RTD 5th 555 Framework Programme, Brussels, Belgium.

Francois, J.F. and Wignaraja, G. (2008) 'Economic implications of Asian integration', Global Economy Journal, Vol. 8, No. 3, Article 1.

Gehlhar, M., Wang, Z. and Yao, S. (2010) 'GTAP 7 data base documentation - Chapter 9.A: reconciling merchandise trade data', available at https://www.gtap.agecon.purdue.edu/ resources/res_display.asp?RecordID=3429 (accessed on 12/6/2011).

Goulielmos, A.M. and Kaselimi, E. (2011) 'A non-linear forecasting of container traffic: the case-study of the Port of Piraeus, 1973-2008', International Journal of Shipping and Transport Logistics, Vol. 3, No. 1, pp.72-99.

Hertel, T.W. (1997) Global Trade Analysis: Modeling and Applications, Cambridge University Press, New York.

Hertel, T.W., Ivanic, M., Preckel, P.V. and Cranfield, J.A.L. (2004) 'The earnings effects of multilateral trade liberalization: implications for poverty', World Bank Economic Review, Vol. 18, No. 2, pp.205-236.

Janic, M. (2007) 'Modelling the full costs of an intermodal and road freight transport network', Transportation Research Part D, Vol. 12, No. 1, pp.33-44.

Kitwiwattanachai, A., Nelson, D. and Reed, G. (2010) 'Quantitative impacts of alternative East Asia free trade areas: a computable general equilibrium (CGE) assessment', Journal of Policy Modeling, Vol. 32, No. 2, pp.286-301.

Kowalski, P. and Shepherd, B. (2006) 'South-South trade in goods', OECD Trade Policy Working Paper No. 40, Organisation for Economic Co-operation and Development, Paris.

Laulajainen, R. (2010) 'Geography sets the tone to tramp routing', International Journal of Shipping and Transport Logistics, Vol. 2, No. 4, pp.364-382.

Lee, P.T-W. and Lee, T.C. (2009) 'An approach to convert the GTAP trade value flows into volume flows', Working paper, Shipping, Port, and Logistics Research Centre, Kainan University, Taiwan.

Lee, P.T-W., Flynn, M., Notteboom, T., Chang, Y.T., Huang, C.H., Chen, T., Lee, T.C. and Chasomeris, M.G. (2008) 'Port economics study', Report of Flynn Consulting Ltd., Hong Kong.

Lee, T.C., Lee, P.T.W. and Chen, T. (2012) 'Economic impact analysis of port development on the South African economy', South African Journal of Economics, forthcoming in Vol. 80. 
Lee, T.C., Wu, C.H. and Lee, P.T.W. (2011) 'Impacts of the ECFA on seaborne trade volume and policy development for shipping and port industry in Taiwan', Maritime Policy and Management, Vol. 38, No. 2, pp.169-189.

Mayda, A.M. and Steinberg, C. (2009) 'Do South-South trade agreements increase trade? Commodity-level evidence from COMESA', Canadian Journal of Economics, Vol. 42, No. 4, pp.1361-1389.

Notteboom, T. (2010) 'From multi-porting to a hub port configuration: the South African container port system in transition', International Journal of Shipping and Transport Logistics, Vol. 2, No. 2, pp.224-245.

Notteboom, T. (2011) 'An application of multi-criteria analysis to the location of a container hub port in South Africa', Maritime Policy and Management, Vol. 38, No. 1, pp.51-79.

OECD (2006) 'South-South trade: vital for development', OECD Policy Brief, available at http://www.oecd.org/dataoecd/30/50/37400725.pdf (accessed on 6/10/2011).

Puri, L. (2007) 'IBSA: an emerging trinity in the new geography of international trade', United Nations Conference on Trade and Development, New York and Geneva.

Sanguinetti, P., Siedschlag, I. and Martincus, C.V. (2010) 'The impact of South-South preferential trade agreements on industrial development: an empirical test', Journal of Economic Integration, Vol. 25, No. 1, pp.69-104.

Song, D.W. and Lee, P.T.W. (2009) 'Maritime logistics in the global supply chain', Editorial, International Journal of Logistics: Research and Applications, Vol. 12, No. 2, pp.1-2.

Veenstra, A.W. and Haralambides, H.E. (2001) 'Multivariate autoregressive models for forecasting seaborne trade flows', Transportation Research Part E, Vol. 37, No. 4, pp.311-319. 